Annals of Warsaw University of Life Sciences - SGGW

Land Reclamation No 48 (3), 2016: 189-200

(Ann. Warsaw Univ. of Life Sci. - SGGW, Land Reclam. 48 (3), 2016)

\title{
On the influence of overconsolidation effect on the compressibility assessment of subsoil by means of CPTU and DMT
}

\author{
ZBIGNIEW MŁYNAREK ${ }^{1}$, JULIAN WIERZBICKI ${ }^{2}$, TOM LUNNE $^{3}$ \\ ${ }^{1}$ Poznań University of Life Sciences \\ ${ }^{2}$ Institute of Geology, Adam Mickiewicz University in Poznań \\ ${ }^{3}$ Norwegian Geotechnical Institute in Oslo
}

\begin{abstract}
On the influence of overconsolidation effect on the compressibility assessment of subsoil by means of CPTU and DMT. The paper contains the analysis of the influence of overconsolidation effect on the values of constrained moduli, assumed by means of two most popular in situ advanced tests. The tested soils included two geological formations: normally consolidated tills of the Pomeranian phase and overconsolidated tills of the Posnanian phase. The overconsolidation ratio $(O C R)$ was derived from $\mathrm{CPTU}$, DMT and oedometric tests. The tests revealed that for the assessment of changes in constrained modulus in the subsoil with CPTU and DMT, the formulas determining the relationship between cone resistance, DMT results and constrained moduli requires empirical coefficient different for soils of varied genesis.
\end{abstract}

Key words: constrained moduli, CPTU, DMT, overconsolidation

\section{INTRODUCTION}

The preconsolidation effect, which occurs in overconsolidated soils, entails the change in mechanical properties of the subsoil in relation to deposits undergoing the process of normal consolidation. This change can be explained with the analysis of the subsoil's behavior according to the "modified Cam-Clay" elastic-plastic model (Burland 1967). Worth and Houlsby (1985) demonstrated that subsoil overload, and subsequent unloading, modifies the position of the envelope elastic state for a given soil. Within the "Cam-Clay" model, the point that can be actually observed while testing subsoil's behavior under the re-load, is the point defining the so called plasticization stress $\left(\sigma_{y}^{\prime}\right)$, and not the overconsolidation stress in the geological sense. In this approach, the change in mechanical parameters of soils does not necessarily have to be connected with historical overload. The necessity to include this fact in the interpretation of the test results was underscored by, among others, Jamiolkowski et al. (1985) and Izbicki and Stróżyk (2006).

Following this way of thinking, it can be assumed that, in the geological process, the series of post-sedimentation changes, which are part of generally understood diagenesis, begin with the deposition of sediment (Jaroszewski et al. 1985, Bolewski and Parachoniak 1988). The beginnings of the early diagenesis, in turn (Pettijohn et al. 1987) are connected with the process of consolidation. Natural consolidation may be both syngenetic and post-genetic. The major interaction that triggers post-genetic consolidation of soil is the force of gravity, and the crucial mechanisms are related to geological and engineering regimes 
(Powell 2005). Phenomena that support consolidation include also desiccation and the influence of hydrodynamic pressure (Jamiolkowski et al. 1985, Wierzbicki and Młynarek 2012, Młynarek et al. 2015). Therefore, it should be assumed that soils are formations at one of early stages of diagenesis. Overconsolidated soils, understood within the geotechnical meaning, may be then at the same stage of diagenesis as normally consolidated soils, i.e. the degree of diagenesis of both kinds of soil may be similar. Hence, as far as geological processes are concerned, the difference between overconsolidated and normally consolidated soils is relative, visible only in the context of the current state of geological environment. These processes are well represented by subsoils found in Poland and Norway.

In this view it becomes crucial not only to determine the general genetic type of soil (e.g. glacial till), but also to consider differences in sedimentary facies (e.g. melt-out till or lodgement till) and the stratigraphic position of the deposits (different phases of glaciation). The present paper aims at identification of these factors and their influence on constrained moduli obtained with CPTU and DMT in-situ tests.

\section{MATERIAL AND METHODS}

\section{Site characterization}

Soils selected for tests were glacial tills widely characterized by homogenous genesis and lithology. However, these formations fundamentally differ in facies (hence, in more broadly understood genesis as well) (Stankowski 1996), which, in turn, leads to substantial differences in geotechnical properties (Wierzbicki 2009). The tests involved the Weichselian glacial tills, which constitute a typical subsoil for Central European lowlands. Two groups of these soils were separated. The first group included glacial tills ( stage, connected with transgression and retreat of Posnanian phase; the second group comprised of younger soils, connected with transgression and retreat of the so called Parseta lobe of the Pomeranian phase (sasiCl). The important geological fact is that the growing Parsęta lobe trespassed on the earlier deposits of Posnanian phase, and then relatively soon retreated by melting of the so called dead-ice (Wierzbicki 2010, Mazurek and Paluszkiewicz 2013). Grain size of the tills of both phases is similar, and the only difference is the smaller amount of sand fraction in the older tills (Fig. 1). Plasticity index of both deposits ranges from 11 to $18 \%$ and the $\mathrm{CaCO}_{3}$ content from 3 to $8 \%$. Therefore, these are the deposits typically occurring in the Central European lowlands (Krygowski 1961). However, noticeable differences do occur in the facial of the sediments. These differences result mainly from the influence of geological processes that lead to the presence of overconsolidation effect in the tills of Posnanian phase, i.e. the lodgement type of deposits, additionally overconsolidated by the transgressing Parsęta lobe. In turn, deposits of the Pomeranian phase belong to the group of melt-out tills, which remained after the rapidly retreating ice sheet. Such a genesis of the tested soils allows for the assumption that the decisive factor influencing geotechnical properties of these soils, including compressibility, would 


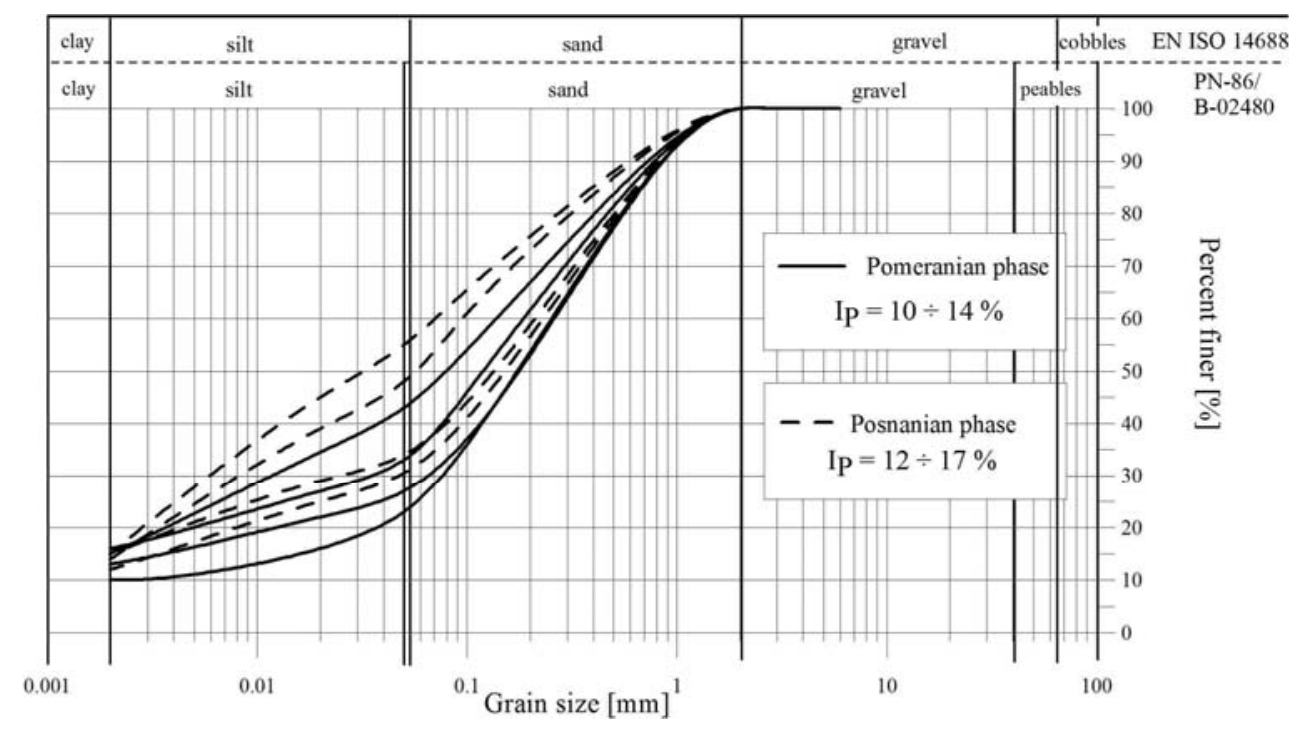

FIGURE 1. Typical grain size distribution of the tested soils

be the variation of the degree of overconsolidation.

\section{Laboratory tests}

The tests for determination of constrained moduli by means of CRS oedometric method were conducted with the Geonor device in compliance with guidelines introduced by Sandbaeken et al. (1986). The undisturbed samples were collected using the MOSTAP $65 \mathrm{~mm}$ sampler. In the CRS test, a sample was being variably loaded with constant value of gradient of corresponding sample deformation in-situ. The test conditions were undrained and the effective value of stress was calculated. Initially, the sample was consolidated to the $\sigma_{\nu 0}$ value, and the actual test was initiated after the value of consolidation stress had been obtained. The test was carried out up to stress value of $900 \mathrm{kPa}$. The sample was then unloaded and re-loaded to a effective stress value of 1.1 MPa. The CRS test provided constrained modulus distribution and graphs of changes in the values of oedometric constrained modulus $\left(M_{o e d}\right)$ in the function of stress changes (Fig. 2). Overconsolidation stress was determined with use of Casagrande's (1936) graphic procedure (Fig. 2a, c) and Janbu et al. (1981) method (Fig. 2b, d). The soil samples, for which exemplary results are provided by Figure 2, were extracted from the depth range of $3.0-3.5 \mathrm{~m}$ of the tested profile. The sample of Pomeranian phase till was extracted from the bottom layer of the profile, whereas the sample of Posnanian phase till from the top of the profile. The obtained results support the hypothesis of the differences in geotechnical properties between both sets of glacial till. Noticeably higher values of overconsolidation stress were received for tills of the Posnanian phase, hence the higher $O C R$ values and twofold higher values of constrained modu- 

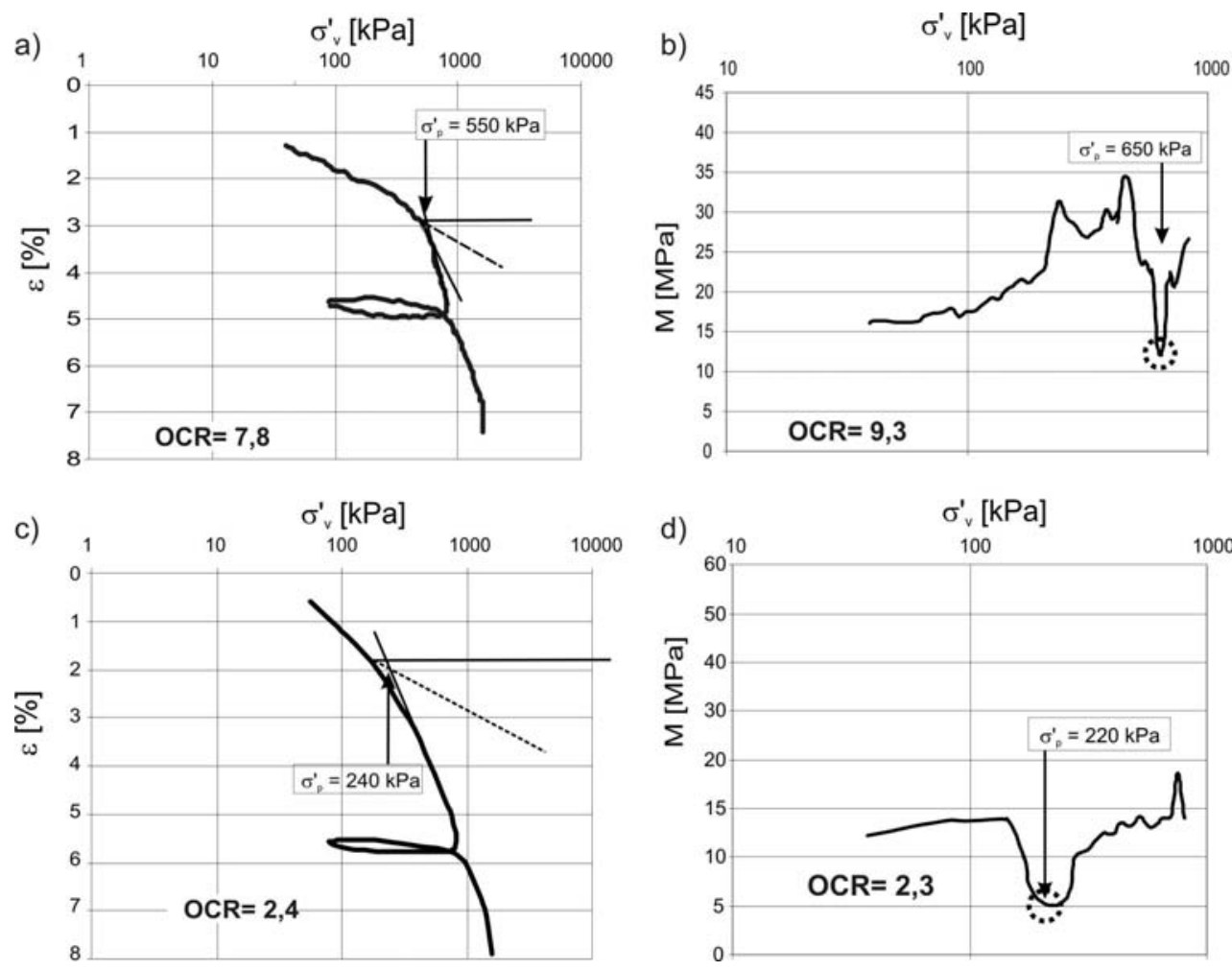

FIGURE 2. Results of oedometric tests of glacial tills of Posnanian phase $(a, b)$ and Pomeranian phase $(c, d)$ and the values of overconsolidation stress, determined via Casagrande's (a, c) and Janbu's (b, d) methods

lus of these deposits in comparison to the Pomeranian phase were found.

\section{In situ tests}

Tests of 12 CPTU static penetration were conducted with the Hyson 20Tf penetrometer in the area of occurrence of the analyzed soils. Additionally, DMT tests were conducted in six places closely located to CPTU tests. As a complementation of these tests, samples for analysis of physical properties of the soil were extracted from boreholes. Based on laboratory tests, grain size distribution and liquidity index were determined. Figure 3 presents results of the tested soils against the lithological profile. Overconsolidation ratio $(O C R)$ was determined using the Marchetti's (1980) formulas (1) and (2) for DMT tests, and Wierzbicki's (2010) nomograms for Polish soils for CPTU tests (Fig. 4). Obtained results were compared with $O C R$ values from oedometric tests, from an open pit in the direct vicinity of the CPTU and DMT tests (Fig. 5).

$O C R_{D M T}=\left(0.5 K_{D}\right)^{1.56}$

$K_{D}=\left(p_{0}-u_{0}\right) / \sigma_{v 0}^{\prime}$

where:

$p_{0}$ - the corrected first reading of pressure in DMT; 

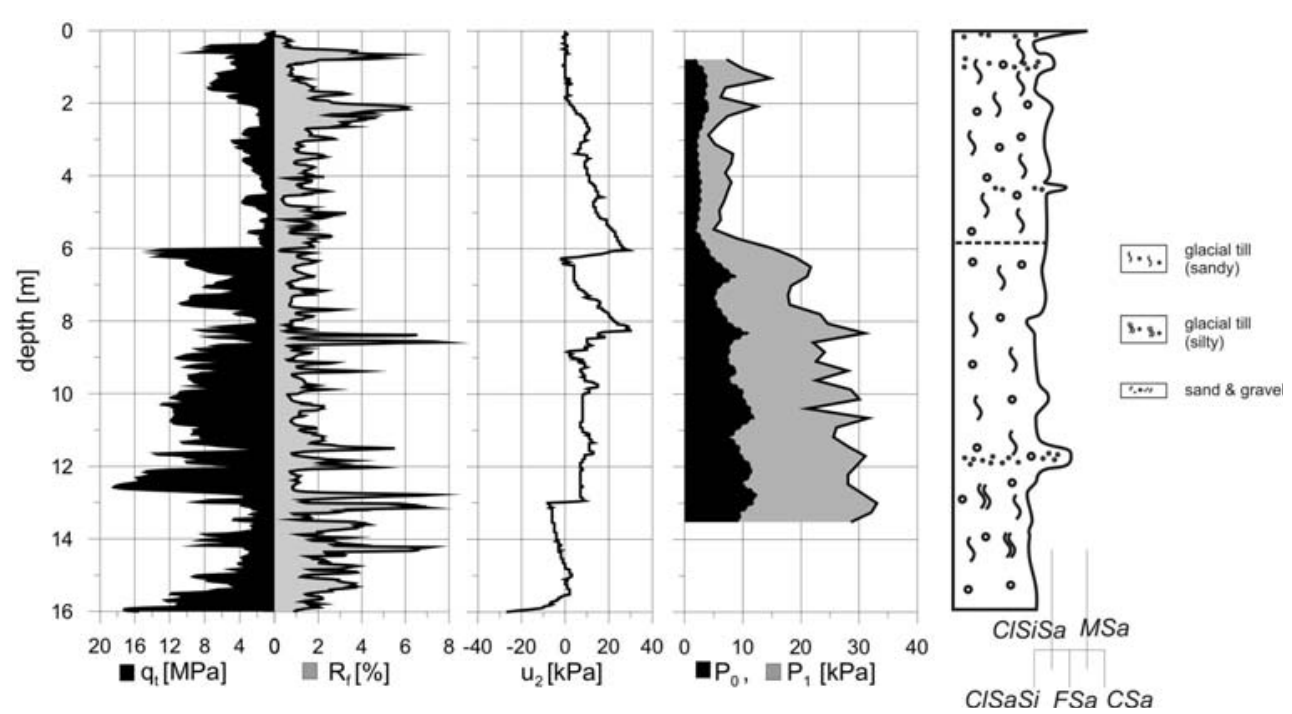

FIGURE 3. Sample results of CPTU and DMT tests in the analyzed soils against the lithological profile

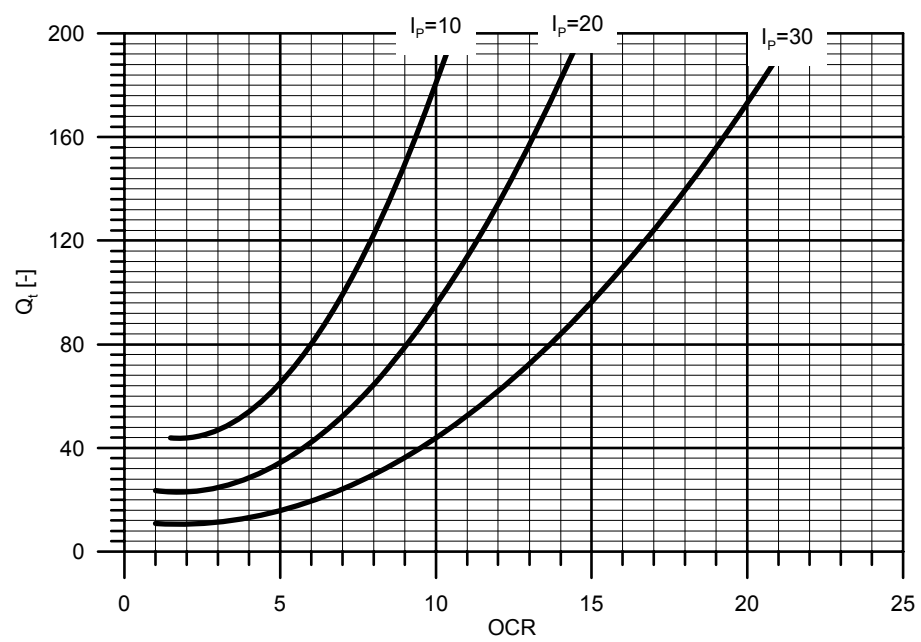

FIGURE 4. A nomogram for calculating the $O C R$ values of cohesive soils with plasticity index $I_{P}<30 \%$, based on the $Q_{t}$ parameter and the $I_{P}$ value (Wierzbicki 2010)

$u_{0}$ - hydrostatic pressure;

$\sigma_{v 0}^{\prime}-$ effective overburden stress.

Figure 5 indicates that both CPTU and DMT methods yield similar results, both concerning the $O C R$ pattern with depth and the actual values of the parameter.
The Pomeranian phase tills are characterized by sharp decrease of $O C R$ with depth, to the value of $2-5 \mathrm{~m}$, and they are visibly separated from the lower tills of the Posnanian phase. On the border between the two sets a clear increase in the $O C R$ values to about 12 can be observed. 


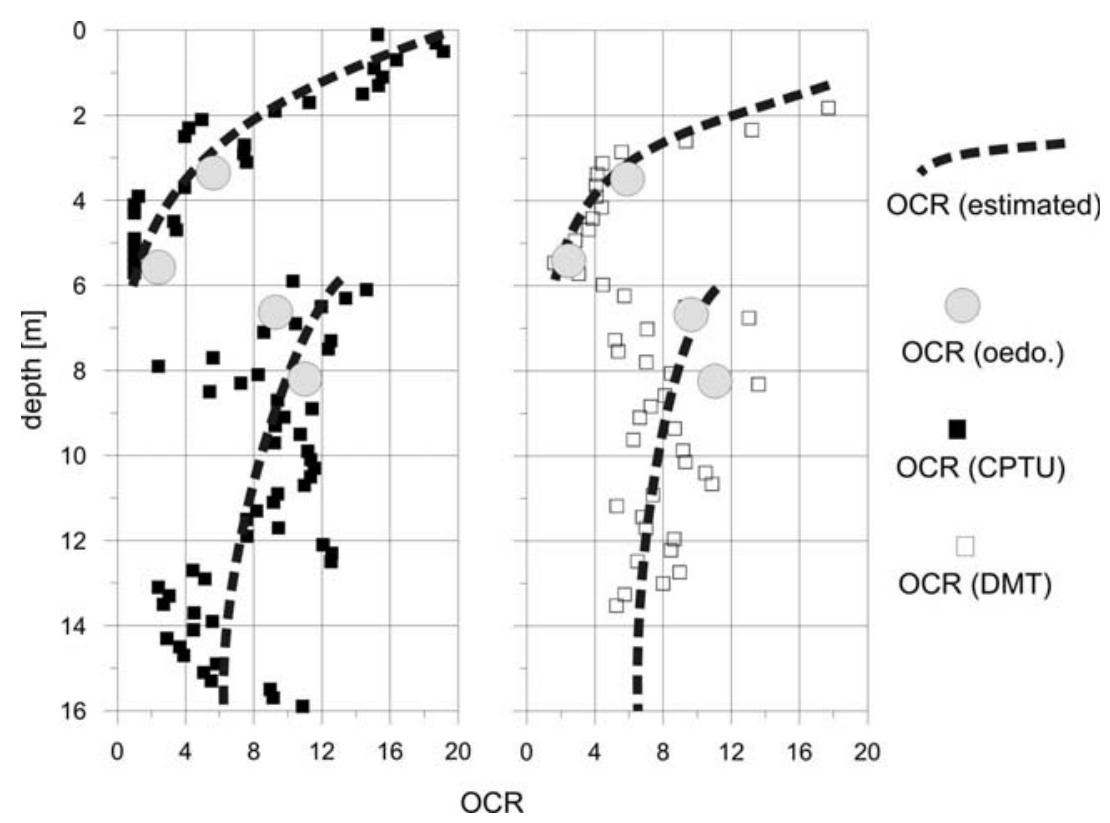

FIGURE 5. Changes in OCR values in the glacial tills profile

Further decline of the $O C R$ values with depth is no more as pronounced as in the younger tills. The results of the in-situ tests interpretation have been confirmed by the laboratory tests results.

\section{RESULTS AND DISCUSSION}

Values of the constrained modulus of tested soils were calculated with Marchetti's formula (3) for DMT tests and with formula (4), commonly used for cohesive soils in Poland, for CPTU tests.

$M_{D M T}=R_{M} E_{D}$

where:

$R_{M}-f\left(I_{D}, K_{D}\right)$ - after Marchetti's equations;

$E_{D}$-dilatometer modulus.

$M_{C P T U}=8.25\left(q_{t}-\sigma_{v 0}\right)$ where:

$q_{t}$ - corrected cone resistance.

The latter formula constituted a starting point for the further analyses aimed at clarification of the relationship between moduli from oedometric tests and from CPTU tests. Values of the constrained modulus were determined also from the CRS tests. The $\sigma_{v 0}^{\prime}$ value for stresses occurring at the depth of soil samples extraction was determined as a reference value. Results of CPTU, DMT and laboratory tests were compared with the $\sigma_{v 0}^{\prime}$ and $\sigma_{p}^{\prime}$ values. Figures 6 and 7 show two distinct trends of changes in the $M_{\text {oed }}$ value depending on $\sigma_{v 0}^{\prime}$ - for normally consolidated and overconsolidated soils. Similar dichotomy dataset can be observed for both in-situ tests (Figs 6,7). However, while in the case of CPTU tests the values of $M_{\text {oed }}$ and $M_{C P T U}$ mod- 


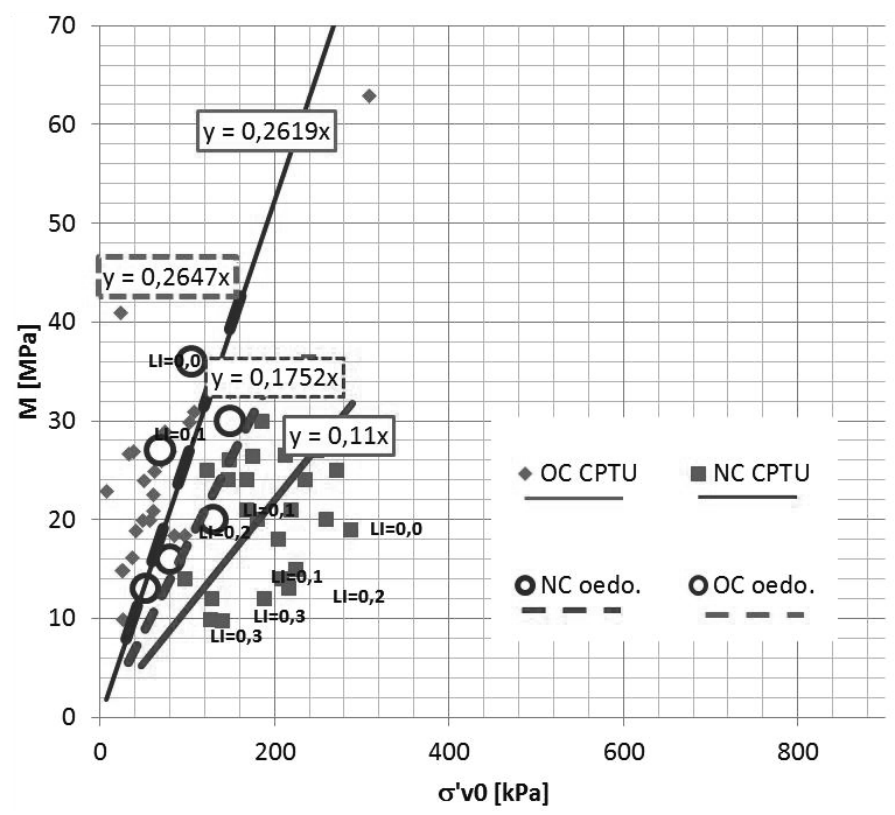

FIGURE 6. $M_{C P T U}$ and $M_{e d}$ moduli variation in comparison to $\sigma_{v 0}^{\prime}$

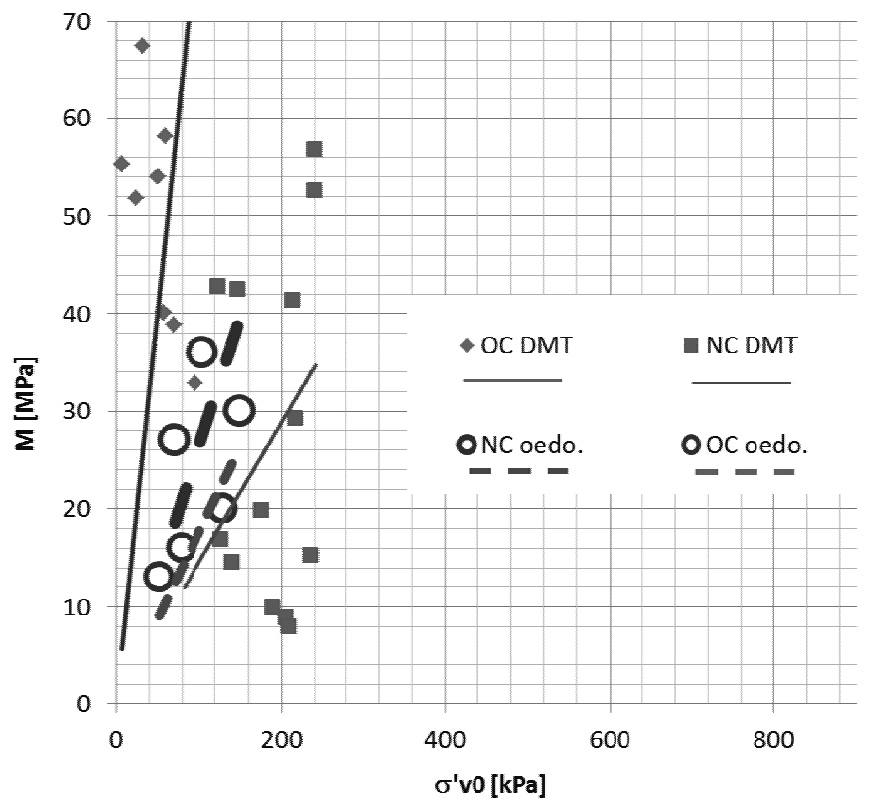

FIGURE 7. $M_{D M T}$ and $M_{e d}$ moduli variation in comparison to $\sigma_{v 0}^{\prime}$ 
uli are similar in overconsolidated soils, $M_{D M T}$ introduces the opposite pattern. The influence of overconsolidation and effective geostatic stress $\left(\sigma_{v 0}^{\prime}\right)$ on the constrained moduli obtained from CPTU and DMT tests are shown in Figures 6, 7 and 8 . It is a generally known principle that in the subsoil composed of lithologically homogenous soils of a nearly constant value of liquidity index, a linear trend of constrained modulus with depth can be observed. In the case of the tested deposits, the constrained modulus is a random variable, because it depends on stress variability $\left(\sigma_{v 0}^{\prime}\right), O C R$ and liquidity index $(L I)$. This fact is well illustrated in Figures 6 and 7. The obtained straight trendlines are characterized by low values of correlation coefficient $\left(0.1<R^{2}<\right.$ $<0.3)$. The other two variables, $\sigma_{p}^{\prime}$ and $L I$, also affect the variation of $M_{C P T U}$ and $M_{\text {oed }}$ moduli with depth. Figure 8 demostrates the effect of $\sigma_{p}^{\prime}$ on $M_{C P T U}$ modu- lus variability. Unambiguity and statistical significance of the influence of this variable are confirmed by high values of correlation coefficient which reached 0.75 for overconsolidated soils. Figures 6 and 7 lead to two crucial conclusions that should be included in the assessment of the constrained modulus values from CPTU and DMT:

- Straight trendlines of $M_{C P T U}, M_{D M T}$ and $M_{o e d}$ moduli variablity clearly separate normally consolidated tills from the overconsolidated ones. This fact substantiates the indication that formula (4) cannot be treated as universal and has to be adjusted by overconsolidation effect.

- A particularly curious element of the analysis is the fact that the impact of overconsolidation effect vanishes in the elastic states of both kinds of till $(L I>0.3)$, and the predicted values of moduli yield in this area similar re-

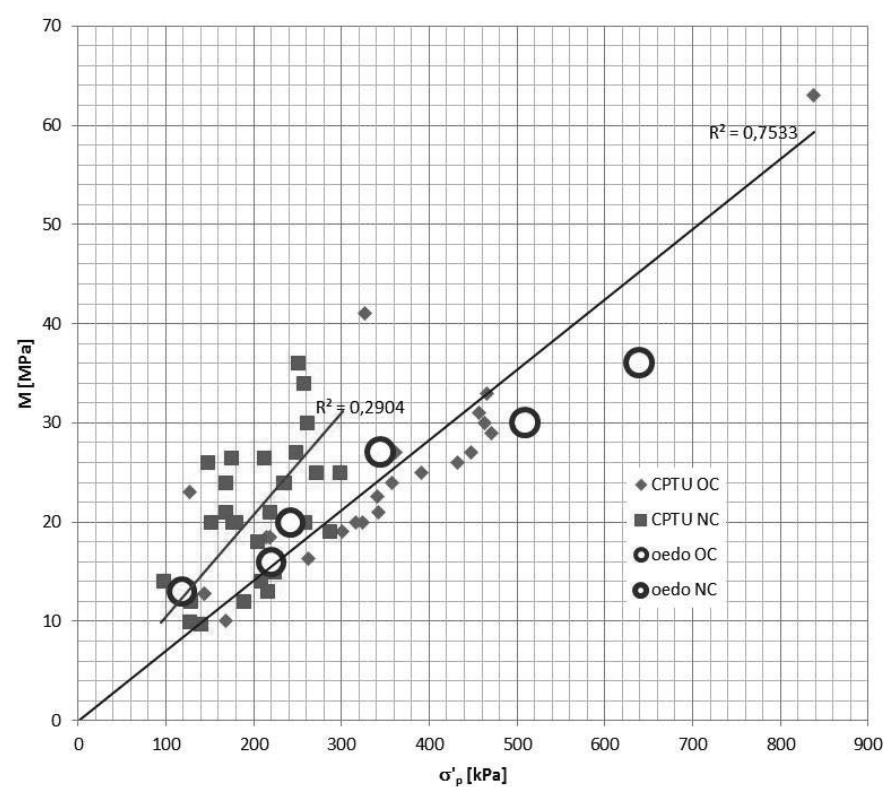

FIGURE 8. $M_{C P T U}$ and $M_{o e d}$ moduli variation in comparison to $\sigma_{p}^{\prime}$ 
sults for all CPTU, DMT and oedometric tests.

In the overconsolidated tills, the application of formula (4) allows for fair estimation of the $M$ value in comparison to oedometric test. Results obtained in normally consolidated tills, in turn, seem to be underestimated compared to the laboratory values. In the case of DMT test, this relationship is opposite - values of the $M_{D M T}$ modulus noticeably exceed the oedometric test results in overconsolidated soils. The corrected value of $\alpha=8.25$ coefficient in formula (4) for normally consolidated tills can be calculated from equations (6) and (7) and used in the final form of equation (8):

$$
\begin{aligned}
& M_{C P T U}=8.25 q_{t}=0.1 \sigma^{\prime}{ }_{v 0} \\
& M_{\text {oed }}=0.175 \sigma_{v 0}^{\prime} \\
& M_{\text {oed }}=8.25\left(q_{t}\right) 0.175 / 0.11=13.13\left(q_{t}\right)
\end{aligned}
$$

where:

$M$ and $q_{t}$ are given in MPa and $\sigma_{v 0}^{\prime}$ in $\mathrm{kPa}$ respectively.

Two different test methods, namely CPTU and DMT, were used to determine the constrained modulus $M$ variability. Moduli obtained from both tests are shown in Figure 9. The figure includes pairs of the calculated $M_{C P T U}$, $M_{D M T}$ moduli marked on the given levels of geostatic stress $\sigma_{v 0}$, as well as the $M_{C P T U}$ values, used in the analysis of the influence of overconsolidation effect on the $M_{C P T U}$ modulus. Values of $M_{C P T U}$ for normally consolidated tills (Fig. 9) were calculated with use of corrected value of 13.13 (eq. 8). Figure 9 reveals that a considerable agreement between $M_{C P T U}, M_{D M T}$ and $M_{\text {oed }}$ moduli independent of soil genesis occurs in elastic states of both kinds of sediments $(L I>0.30)$. In the stiff and very stiff soils, the proportionality coefficient between

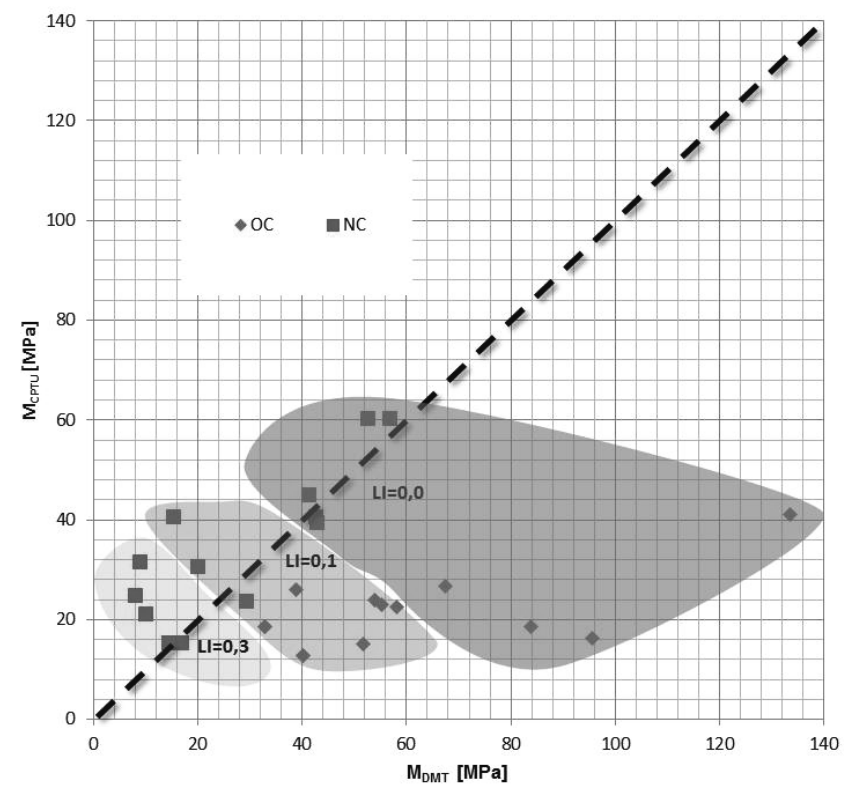

FIGURE 9. Comparison of $M_{C P T U}$ and $M_{D M T}$ values with $M_{\text {oed }}$ modulus 
$M_{D M T} / M_{C P T U}$ and $M_{D M T} / M_{\text {oed }}$ moduli changes depending on liquidity index, and it reaches the value of 3.0. The use of $M_{D M T}$ modulus to predict changes in $M_{\text {oed }}$ in the stiff soils requires calibration. For overconsolidated tills from the area of Warsaw, Lechowicz et al. (2011) proposed a calibration method in which the $R_{M}$ coefficient changes. The occurrence of this problem in the zone of eolian sediments was demonstrated by Stefaniak (2014). One possible reason for varying assessment of the $M_{\text {oed }}$ moduli with use of DMT tests is a significant influence of horizontal geostatic stress $\left(\sigma^{\prime}{ }_{h 0}\right)$ on the measured DMT parameters.

\section{CONCLUSIONS}

The conducted tests confirmed two general and essential hypotheses. The first hypothesis was that CPTU and DMT allow for the identification of subsoil overconsolidation effect that is connected with soil genesis. The second one stated that the overconsolidation effect influences the values of constrained moduli clearly and unambiguously. Inclusion of the influence of overconsolidation effect on the values of constrained moduli variation is made possible with introduction of such variables as $O C R$ coefficient and plasticity index into the formula for the relationship between cone resistance (CPTU) and constrained modulus $\left(M_{o e d}\right)$. This way of deformation moduli assessment has been known for shear modulus - $G_{0}$ (e.g. Hardin 1978, Młynarek et al. 2013). However, such a solution requires a great number of tests in soils of varied genesis and grain size. Another way is the proposed method of separating nor- mally consolidated and overconsolidated soils in the subsoil. A preliminary method of soil classification into one of these categories may be use of CPTU classification charts (Lunne et al. 1997). At the second stage, $O C R$ or $\sigma_{p}^{\prime}$ values need to be determined for each group. For overconsolidated deposits, formula (4) can be recognized as satisfactory for determination of changes of constrained moduli in the subsoil. In the case of normally consolidated tills, the formula modified with the 13.13 coefficient can be used. It has to be remembered that in soils of massive macrostructure, e.g. alluvial soils and loess, values of this coefficient may be different.

\section{REFERENCES}

BOLEWSKI A., PARACHONIAK W. 1988: Petrografia. Wydawnictwa Geologiczne, Warszawa.

BURLAND J.B. 1967: Deformation of soft clay. $\mathrm{PhD}$ Thesis. University of Cambridge, UK.

CASAGRANDE A. 1936: The Determination of the Preconsolidation Load and its Practice Significance. Proc. $1^{\text {st }}$ ICSMFE, Vol. 3, Cambridge, Mass. 60-64.

HARDIN B.O. 1978: The nature of stressstrain behavior for soils. Proc. ASCE Geotechnical Div. Specialty Conf. on Earthquake Engng and Soil Dynamics, Pasadena, 3, 90.

IZBICKI R., STRÓŻYK J. 2006: Stopień YSR miarą prekonsolidacji iłów formacji poznańskiej. Zesz. Nauk. P. Biatost., Bud. 28, 1, 117-126.

JAMIOLKOWSKI M., LADD C.C., GERMAINE J.T., LANCELLOTTA R. 1985: New developments in field and laboratory testing of soils. Proc. $11^{\text {th }}$ ICSMFE, San Francisco, Vol. 1. 57-154. 
JANBU N., TOKHEIM O., SENNESET K. 1981: Consolidation Tests with Continuous Loading. Proc. $10^{\text {th }}$ ICSMFE, Stockholm, Vol. 1, 645-654.

JAROSZEWSKI W., MARKS L., RADOMSKI A. 1985: Słownik geologii dynamicznej. Wydawnictwa Geologiczne, Warszawa.

KRYGOWSKI B. 1961: Geografia fizyczna Niziny Wielkopolskiej: Geomorfologia. Część 1. PWN, Warszawa.

LECHOWICZ Z., RABARIJOELY S., GALAS P., KIZIEWICZ D. 2011: Settlement evaluation of spread foundations on heavily preconsolidated cohesive soils. Ann. Warsaw Uni. Life Sci. - SGGW, Land Reclam. 43(2), 111-118.

LUNNE T., ROBERTSON P.K., POWELL J. 1997: Cone penetration testing in geotechnical practice. E\&FN Spon, London.

MARCHETTI S. 1980: In situ tests by flat dilatometer. ASCE, JGED, V. 106, No. GT3, 299-321.

MAZUREK M., PALUSZKIEWICZ R.E. 2013: Formation and development of a 1st-order valley network in postglacial areas (the Dębnica catchment). Landform Analysis, 22, 75-87.

MŁYNAREK Z., WIERZBICKI J., MAŃKA M. 2015: Geotechnical parameters of loess soils from CPTU and SDMT. S. Marchetti, P. Monaco, A Viana da Fonseca (Eds.). International Conference on the Flat Dilatometer DMT'15, Rome, 481-489.

MŁYNAREK Z., WIERZBICKI J., STEFANIAK K. 2013: Deformation characteristics of overconsolidated subsoil from CPTU and SDMT tests. R.Q. Coutinho, P.W. Mayne (Eds.). Geotechnical and Geophysical Site Characterization 4 - Proc. of $4^{\text {th }}$ International Conference on Geotechnical and Geophisical Site Investigation. Taylor \& Francis Group, London, 1189-1193.

PETTIJOHN F.J., POTTER P.E., SIEVER R. 1987: Sand and sandstone. Springer-Verlag, New York.
POWELL J.M. 2005: In situ testing. General report. Proc. of $14^{\text {th }}$ International Conference on Soil Mechanics and Geotechnical Engineering, Millpress, 729-734.

SANDBAEKKEN G., BERRE T., LACASSE S. 1986: Oedometer testing at the Norwegian Geotechnical Institute. Consolidation of soils: testing and evaluation; a symposium. ASTM, Special Technical Publication 892, 329-353.

STANKOWSKI W. 1996: Podstawowe facje glin morenowych oraz kryteria ich wyróżniania. Geologos 1, 150-157.

STEFANIAK K. 2014: Wybrane osady aluwialne jako podłoże budowlane i materiał do budowli ziemnych. $\mathrm{PhD}$ thesis (in Polish). University of Life Science, Poznań, Poland.

WIERZBICKI J. 2009: Analysis of changes in overconsoildation ratio in selected profiles of non-lithified deposits. $A C E E$ Journal 3, 77-84.

WIERZBICKI J. 2010: Evaluation of subsoil overconsolidation by means of in situ tests at the aspect of its origin. Rozprawy Naukowe UP Poznań 410.

WIERZBICKI J., MŁYNAREK Z. 2012: Identification of overconsoildation effect by means of in situ tests. Inż. Mor. Geotech. 4, 277-285.

WORTH C.P., HOULSBY G.T. 1985: Soil mechanics - property characterization and analysis procedures. Proc. of $11^{\text {th }}$ ICSMFE, San Francisco, Vol. 1.

Streszczenie: Wptw efektu prekonsolidacji na ocenę ściśliwości podtoża metodami CPTU i DMT. W artykule przedstawiono analizę wpływu efektu prekonsolidacji na wartości modułu ściśliwości, wyznaczane na podstawie zaawansowanych badań in situ, CPTU i DMT. Badane grunty były glinami zwałowymi, należącymi do dwóch formacji geologicznych: fazy poznańskiej i fazy pomorskiej zlodowacenia wisły. W ramach badań określono wartości współczynnika prekonsolidacji gruntów, zarówno w badaniach laboratoryjnych, jak i na podstawie wyników CPTU i DMT. Przeprowadzone analizy korelacji warto- 
ści modułu ściśliwości z badań edometrycznych oraz wyników badań in situ wykazały, że ocena modułu ściśliwości na podstawie badań CPTU i DMT wymaga stosowania różnych współczynników korekcyjnych w zależności od genezy gruntu.
MS received June 2016

\author{
Authors' address: \\ Jędrzej Wierzbicki \\ Instytut Geologii \\ Wydział Nauk Geograficznych i Geologicznych \\ Uniwersytet im. Adama Mickiewicza \\ ul. Bogumiła Krygowskiego 12, 61-680 Poznań \\ Poland \\ e-mail: jwi@amu.edu.pl
}

